\title{
Reassessment of the Soviet agrarian policy in the light of today's achievements
}

\author{
S. Merl
}

Stephan Merl, DSc (History), Professor, Bielefeld University; 25 Universitätsstr., 33615, Bielefeld, Germany. E-mail: smerl@uni-bielefeld.de.

Obvious successes of Putin's policy require a reassessment of the Soviet agrarian policy. The article addresses the question of whether the Bolsheviks' approach was appropriate for the Russian peasantry and considers limitations of the concept "socialist industrialized agriculture'. To assess achievements of the Soviet agriculture the author uses qualitative instead of quantitative criteria: per hectare yields and milk per cow since 1913. They kept to be extremely low which is striking for the agriculture based on large-scale and partly mechanized production. The gap in yields as compared to the neighboring capitalist countries even widened from 1930 to 1991 . The strong and steady growth in yields since 2000 does not allow to explain failures of the Soviet agriculture by bad soils, specific climate or natural limitations - the Soviet agrarian policy is to blame. Instead of "revolutionizing", socialist agriculture did not take part in any significant productivity rise as elsewhere in the world during the "green revolution". The author argues that the main reason for such a failure was "infantilization" of agricultural producers - peasants, heads of state and collective farms - by a combination of mistrust and scrupulous control. During the Soviet period agricultural producers never were the masters of their fields. The situation became even worse after the planned economy provided agriculture with insufficient and ineffective machinery below Western standards. Although necessary machinery and knowledge of organizing the production were available in the West, in the Soviet Union the mechanization of crop production and animal husbandry was not completed. The article starts with the description of peasants' interests, behavior und expectations in the Revolutions of 1905 and 19171918; then the author focuses on the foundations of the Soviet agrarian policy suggested by Lenin and Stalin, continues with a short review of different approaches to agriculture developed by Khrushchev, Brezhnev und Gorbachev, and finishes with a summary of the reasons for Putin's successes paying special attention to the short periods of yields growth - 1924-1930, 1953-1958, 1965-1970, and 1986-1991.

Key words: socialist agriculture, agrarian policy, industrialized agriculture, infantilization of peasants, class differentiation, V.I. Lenin, J.V. Stalin, N.S. Khrushchev, L.I. Brezhnev, M.S. Gorbachev, V.V. Putin

DOI: 10.22394/2500-1809-2019-4-1-45-69

\section{Introduction}

After the October Revolution, the Bolsheviks seized power in the peasant country. The overwhelming majority of the Russian population (about $8_{5}$ percent) lived in the countryside consisting of peasant 
46 land communes engaged mainly in agriculture. The Bolsheviks were not ready to unite with peasants, they relied on the world proletarистория iat and urban workers and expected that the West-European working class and not the backward Russian peasants would join the proletarian revolution. Unlike the Social Revolutionaries (SR), they did not communicate with rural population and their ideas of socialist agriculture reflected the Marxist theory. They expected to get revolutionary agricultural productive forces just by transition to socialist agriculture consisting of large-scale enterprises. Economic planning instead of "anarchy of the market" was their key idea: they believed that its rapid introduction would lead to the substantial rise in yields (Merl, 1993: 15-78).

Until 1917 the Bolsheviks never questioned whether their concept of socialized agriculture fit the social-economic situation of the Russian peasantry and was acceptable for them. While in Western Europe industrialization was already developing and peasants flew from the countryside to find jobs in urban areas, the situation in Russia was totally different. Even after the industrialization began in the mid-1880s, the demand for labor in the cities was not sufficient for quickly growing rural population. The Bolsheviks faced rural underemployment (hidden unemployment in the countryside), and any project of industrialized socialist agriculture setting free more labor would only aggravate the problems.

In the summer of 1917 , Lenin realized that to take power he had to offer something to peasants. To win their support, he used "peasant electoral mandates" collected by the SRs in mid-1917 and claiming redistribution of the estates' land, which contradicted the previous Bolshevik program of making the estates as large-scale enterprises a new form of state property. Thus, the "Decree on Land" published a few days after the October Revolution legalized the already ongoing peasants' confiscation and redistribution of the nobles' land. Tactically Lenin's plan succeeded: the land decree won peasants' support for the "reds". When the civil war broke out in 1918, it went without saying that the majority of peasants fought against the "whites" who wanted to return the illegally expropriated land to the noble land owners (Merl, 2017a).

In assessing political failures and successes of the Soviet agricultural policy, I will consider the Bolshevik socialist industrialized agriculture approach's suitability for the Russian peasantry - to win their trust and involve them in socialist reconstruction.

\section{Preconditions}

Russian agriculture since the 18th century showed a strong path dependency. There was always a combination of small and large-scale agriculture. After Alexander II emancipation decree both (serf) peas- 
ants and large-scale noble estate owners had about half of the arable land. Later and despite peasants' complaints, the distribution of land changed in peasants' favor. In 1900 , only 20 percent of land still belonged to estate owners. If we take into account land leasing, peasants cultivated about go percent of arable land.

Peasant communes distributed land by the number of males in the household. Due to the population growth (about 2 percent annually), the medium size of land per person was quickly shrinking though every rural household had access to land. The worsening land/man ratio under the prior grain production put pressure on rural households and made peasants demand more land in the Revolutions of 1905 and 1917. They required redistribution of the estate owners' land. From the economic point of view, this was meaningless: the problem was not in the size but in the use of land. Without intensification of agricultural production after the redistribution of land under the demographic pressure the same land/man ratio would return in just few years! To solve peasants' problems and to raise their incomes, the extensive use of land had to be changed by an agricultural reform rather than a revolution.

Agricultural development always strongly depended on external pressure. Urban workers have a higher demand for meat and milk products than rural people, and only industrialization could overcome the hidden rural underemployment by a new productive use of available labor outside agriculture. Although migration from rural areas and agricultural production started in the 1890 s, it was not yet strong enough for the intensification of land use by rural households. Only growing consumption of meat products in the cities and growing demand for industrial crops could stimulate the necessary development of the Russian market (Merl, 2017a).

Under the early 19th century emancipation elsewhere in Europe, the use of land started to improve: redistribution of communal land, transition to better crop rotations, improved seeds, etc. This was the aim of the 1906 Stolypin reform falsely accused of defending only the property rights of strong peasants. Under this reform, state credit became available for rural credit cooperatives, and secondary and higher educational institutions introduced agricultural courses.

The Bolsheviks' idea of the large-scale mechanized agriculture contradicted not only peasants' expectations but also economic needs of the country suffering from heavy rural overpopulation. The Bolshevik idea of the peasant class differentiation was even more strange for peasants as based on the questionable Marx idea of transition of peasant economy to small commodity production reproducing capitalism. Therefore, Bolsheviks thought they had to confront individual peasants as "petty capitalists" (Krebs, 1983). They considered individual peasants as potential counter-revolutionaries and identified only a strange stratum of "poor peasants" as class allies. We have to question this approach for even many seemingly successful farms in Rus-
47

S. Merl

Reassessment of the Soviet agrarian policy in the light of today's achievements 
sia were pretty small compared to the European ones. The majority of rural households were small or medium-sized with an income significantly lower than of urban workers (Merl, 199ob).

Traditionally Russian peasants supported the "myth of the tsar": they wanted to trust the monarch but demanded justice in return. The peasants' idea of justice denied the nobles' right to use the "god's acre". They wanted a just monarch to confiscate the nobles' land and redistributed it among peasants. The Bolsheviks' idea that the peasant revolts were against exploitation by noble landowners and that peasants were a part of the class war under the social differentiation was totally wrong. Lenin mistook the peasant revolt for justice for social revolution. Like the intelligentsia, he did not see the real demands of peasants: they used violence only to protect their view of justice. Revolts against noble landowners were the dominant form of Russian peasant's protest until 1917. They were legacy of serfdom and noble exemption from obligatory service to the tsar in 1762 , and were based on moral rather than economic or social demands (Merl, 2017a). In economic terms, the noble land use significantly decreased already in 1900, redistribution of this land could not solve peasant problems.

After the 1861 emancipation, peasants expected to get all land but got only personal freedom. Moreover, the tsar made them buy land from noble landowners and bargain about conditions of the deal. Thus, the tsar gave peasants something new in addition to the feeling of justice: for the first time in history he addressed them in the decree as citizens with equal rights and acknowledged them as equal partners to noble landowners. Although peasants were greatly dissatisfied, this unexpected concession put them into a kind of a shock paralysis. To get their justice, they used the right to resist as they understood it by accepting the rule of the tsar.

To understand peasant activities, one should remember that they sought legitimization for every revolt, which could be granted only by the peasant commune assembly, i.e. peasant decisions were justified by the collective vote - both local affairs and protests against local estate owners. Only if neighboring communes had the same voting uprisings could spread regionally. The violence started right after the vote, so it lacked any intensive preparation. The pure local character limited the scope of the Russian peasant protest: even in the 1917 Revolution, the conflict was local - between the noble land-owner and the peasant commune - although throughout the country (but neighboring communes could keep peaceful relations with their landowners). If the state violated justice, which affected all peasant communes at the same time, the uprising could spread all over the country and even threaten the rule. Such protests started only under the Bolshevik rule: first, as a "peasant war" against the Bolsheviks taking grain by force in 1918-1921, and then in babie bunty in 1930 against the confiscation of cows during forced collectivization (Schedewie, 2006a; Merl, 2017a). 
The basic misunderstanding between the Bolsheviks and the peasantry can be illustrated by the question: who had to thank whom for redistribution of landholdings? Lenin believed that peasants had to thank the Bolsheviks for land redistribution and providing them with the nobles' land, while peasants perceived the situation differently: they took land by their own and only the land that belonged to them by the law. The Bolsheviks believed that they gave "more land" as a huge gift to "poor" peasants, while peasants did not gain much. The land was redistributed within land communes according to the number of male household members. Poor peasants might have got a little bit more land but their dependency on farm implements became stronger, and there was no redistribution of farm implements (machinery, working cattle). Thus, land redistribution only nominally made rural households "equal" (Merl, 2017a).

From 1861 to 1903 , open revolts were rare. Under the agricultural modernization, at the turn of the century, many estate owners enhanced the use of landholdings, which led to conflicts over peasants' illegal use of meadows and forests of noble landowners. The estate owners planted new cultures (for example, sugar beet) and increasingly used agricultural machinery, which hurt peasant interests: agricultural machinery reduced the landowners request for seasonal labor and the size of land leased to peasants. As a result, the growing land rent and decrease in salaries led to violent protests (Schedewie, $2006 \mathrm{~b})$.

Peasants interpreted the 1905 October Tsar Manifest as allowing them to take the nobles' land by force although the manifest did not mention peasants at all. However, landowners tried to hide the existence of the manifest, the rumors spread, and peasants became sure that the nobles tried to cheat them by hiding the just tsar's will that would finally eliminate the nobles' land property (Ascher, 1988). Unlike peasant unrest in the Baltic states or Caucasus, the Russian peasant uprisings in 1905 had local character and were against local landowners rather than monarchy. But the outcomes changed the peasants' attitude to the tsar Nicolas II significantly. The bloody suppression of rebellions made him look a false tsar and determined the politicization of peasants.

The peasant perception of the 1917 February Revolution was very positive. When the Provisional Government finally put the peasant question on the political agenda, peasants already wanted to see a new ruler. The only thing he could do was to declare that all land belonged to peasants, and they considered the land question on the agenda as legitimating their violent attacks on the nobles' estates.

Thus, the peasant revolution started independently from the Bolshevik revolution already in mid-1917 and followed its own agenda. Peasants confiscated the nobles' land and often burnt down their manor houses. They wanted to make sure that the nobles never return. By the beginning of the October Revolution, peasant activities had

\section{S. Merl}

Reassessment of the Soviet agrarian policy in the light of today's achievements 
50 already significantly changed the local situation. By confiscating the nobles' land and overthrowing local administration and police, peasants destroyed the basis of the tsarist rule in the countryside. Peasants were taking power and establishing a new local order based on village soviets (Channon, 1988; Figes, 1989). Lenin's Land Decree legitimized peasant actions, but peasants expected the Bolsheviks to accept them as equal partners and provide with equal rights as workers such as creating peasant unions (they already existed in 1905). Despite the Land Decree, the confiscations of land continued without the Bolsheviks who only in the spring of 1918 got control over the countryside. Meanwhile peasants confiscated the nobles' land in neighboring regions too and often started land distribution within peasant communes, i.e. their local rule did not confront the Bolshevik rule.

The tsarist regime failed to ensure the food supply of the army and cities, and so did the Provisional Government. The Bolsheviks' decision to introduce prodrazverstka instead of the tax in kind worsened their relations with peasants for it was more arbitrary. The class approach led the Bolsheviks to conflicts with middle and well-to-do peasants. Instead of making a strong union with peasants against the "whites", the Bolsheviks put peasants under strong pressure and martial law. Already in 1918, control and mistrust were basic features of the Bolsheviks' approach to the peasantry. While peasants wanted to speak with the new rulers, Lenin decided not to have negotiations with them and chose a military solution (Danilov, Shanin, 2002).

The situation changed after the victory over the "whites" - peasants started to revolt against taking their grain by force. Disappointment and brutal grain requisition made peasants start a war against the Bolsheviks who had lost the image of just rulers. Thus, the war of 1918-1922 was the Bolsheviks' war against the peasantry. Peasants fought against brutal confiscation of their grain but not against the Bolshevik power as such. Unlike previous peasant uprisings, from 1918 the brutal violence of both sides was primarily directed against persons. The Bolsheviks used prodrazverstka to punish peasants who for some time were under the rule of the "whites". After they won the territory again they demanded the double amount of grain from peasants suspecting them hiding a lot of grain. The amount of grain taken by force in the Volga and Siberia Regions was too high (Danilov, Shanin, 2002; Merl, 2017a). Severe military fights between rebellious peasants and the Red Army reached its peak in 1920.

The events of 1917-1922 changed the Bolshevik-peasant relations to the worse. The Bolsheviks denied peasants' contribution to the success of the October Revolution and denied them equal civil rights. Lenin's kombedy (committees of poor peasants) aiming at grain requisition failed, and the majority of peasants considered them an affront. Peasant uprisings of 1917-1918 against the estate owners based on the collective vote of local assemblies strengthened peasant solidarity while Lenin tried to split them into "classes". 


\section{Assessment of the agrarian policy: An overview of per hectare and per cow yields}

To assess the Soviet agriculture, we should consider qualitative rather than quantitative criteria. Graphs 1-3 show the development of per hectare and per cow yields over the given period on the contemporary territory ${ }^{1}$.

The graphs prove that yields in the Soviet period were extremely low and until the end of Stalin's rule were equal to other parts of Europe at the beginning of the 18th century, i.e. to the pre-industrial agriculture. This is even more striking for the Soviet agricultural production under Stalin in the 1930 s became large-scale and partly mechanized. Despite small increases in the mid-1950s and in the second half of the 1960 s, yields lagged behind neighboring European countries. A strong upward trend in yields appears only in 2000, which proves that Soviet failures cannot be explained by bad soils, climate or natural limitations: the Soviet agricultural policy is to blame.

The main reason for such failures was "infantilization" of agricultural producers by a combination of mistrust even to large-scale agricultural enterprises with a scrupulous state control, which led to the state command over every step of production and distribution until the end of perestroika. Agricultural producers were never masters of their fields. They were often forced to execute crazy state orders destroying crop rotation. The poor supply of agricultural machinery of miserable quality, permanent lack of spare parts and neglect of agricultural technology decreased agricultural productivity and deprived peasants of the interest to decent work. Agricultural and industrial production of the command economy had significant differences: from the director of an industrial enterprise Stalin would demand only to complete the production plan; after re-establishing of the one-leader principle in 1931, he would not interfere in the director's production arrangements; thus, industrial directors became masters of their enterprises with some specific rights such as the use of corruptive practices (Merl, 2010; Merl, 2017b).

To make my conception clear, I will focus on the short periods of high yields such as the 1920s under Lenin's political turn to the "middle peasant": yields stabilized after the disasters of "war communism" and the famine of 1921-1922 although there was no large-scale produc-

1. The graphs are based on the date before 1980-1985 for the Soviet Union, from 1986 onwards - for Russia. From 1970 to 1985 data are available for both the Soviet Union and Russia. Concerning milk yields, the data are nearly equal. Potato yields were slightly higher in the Soviet Union (up to 10 percent), grain yields were up to 20 percent higher. Only for sugar beet the difference was quite significant: about 220-230 dt/hectare in the Soviet Union and 160 in Russia. However, this means that the increase in yields in Russia was even more impressive than the graphs suggest.
Reassessment of the Soviet agrarian policy in the light of today's achievements 


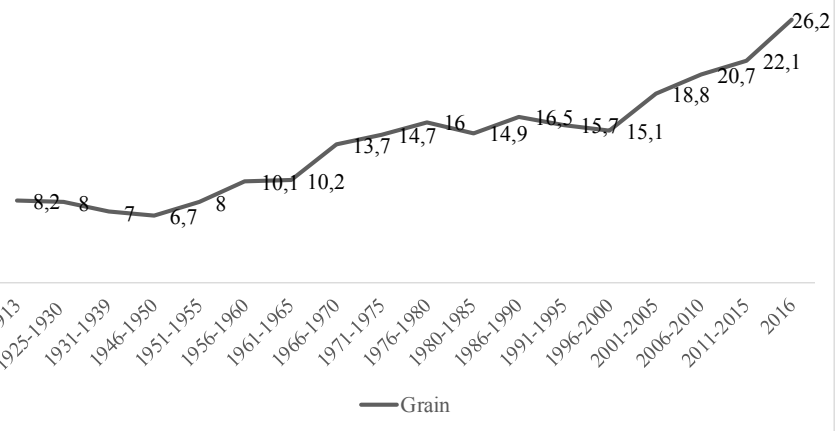

Graph 2: Per hectare yields of sugar beets and of potatoes (in $100 \mathbf{~ k g}$ )

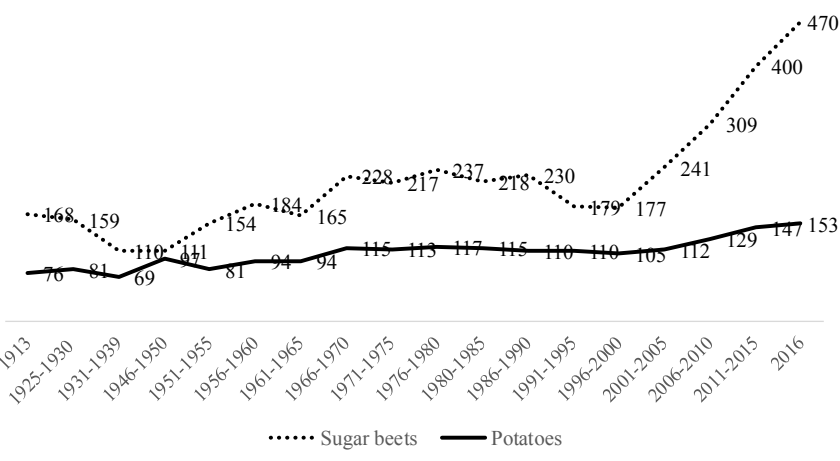

\section{Graph 3: Annual milk yields per cow (in kg)}

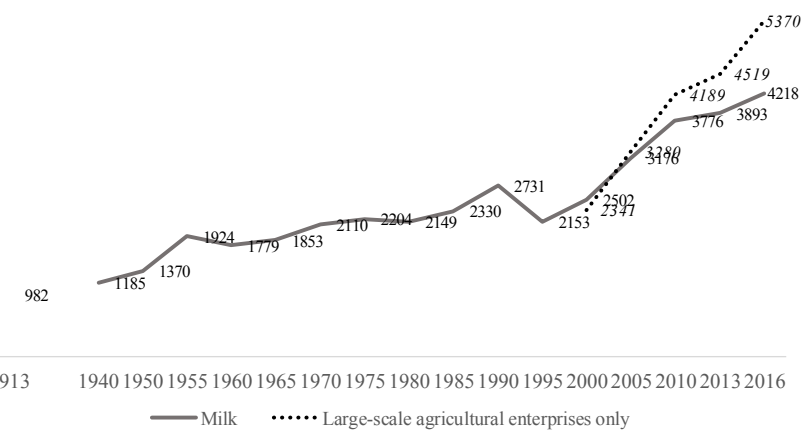

Sources: Merl, 1990a: 40; Selskoe khoziaistvo, 1988: 13-17; Rossiisky statistichesky ezhegodnik, 2007: 448-462; 2014: Tables 15.17 and 15.35; 2017: Tables 16.18 and 16.29. 
tion after the liquidation of estates. From the early 1930s to Stalin's death there was a period of dramatic failure: the forced turn to largescale agriculture by collectivization made yields fall lower than the peasant agriculture in the 1920s. After Stalin's death under Khrushchev's rule, an increase in yields quickly turned into new stagnation on a higher level. Under Brezhnev's rule the state capital investments in agriculture became significant. At first the yields increased, but then the growth stopped. Liberalization under Gorbachev's rule determined a short-term upward trend. The decline in urban demand for meat and milk products led to the decline of agricultural production from 1992. After privatization in agriculture, Putin's new approach to agrarian policy became effective from the 2000s. It is based on large state subsidies and food security doctrine. Now enterprises decide by themselves on inputs including the choice of machinery, seeds and knowledge, which led to a gradual and sustainable increase in yields (Wegren, Nikulin, Trotsuk, 2018).

I will start with the New Economic Policy in the 1920s, try to answer the question why yields under Stalin's rule were so low, describe the agricultural policy based on mistrust und scrupulous control, then consider changes in agricultural policy after Stalin's death under Khrushchev, Brezhnev, and Gorbachev's rules. Finally, I will explain the fast growth of yields under Putin's rule.

\section{New Economic Policy (1921-1928)}

Economic disasters of the war communism and the loss of hope that West European workers would join the Bolshevik revolution made Lenin change his approach to the peasantry. He understood that peasants had to be integrated into the Soviet state, which was the final acceptance of class relations in backward Soviet Russia: though the Bolsheviks successfully suppressed peasant rebellions in 1920-1922, they had no alternative than to integrate them in the new social order. It took Lenin a long time to accept the middle peasants as partners. This started with the replacement of prodrazverstka by a tax in kind on grain in the early 1921, thus, peasants returned the legal right to sell their surplus products in the market, which was the start of the New Economic Policy and acceptance of all social groups in the construction of socialism.

Instead of class differentiation, rural households in the 1920s differed by their ability to work on their land alone, dependence on others, and economic orientation. Those able to work with their own implements and cattle can be called middle peasants. Their share in the non-black-earth area was about two thirds, in the black-earth area - about one third of households. Other rural households either had to lease part or all implements from other peasants or (usually in the black-earth steppes) were working in pairs for four horses were
Reassessment of the Soviet agrarian policy in the light of today's achievements 
54 needed for the heavy plough. Less than one percent of households can be called kulaks for the redistribution of land during the peasant revoистория lution of 1917-1918 contributed to the equal division of land per person. There hardly were landless rural households and agricultural workers for the village commune distributed arable land among all families.

Another important criterion of differentiation was the main source of income. For many households, agricultural income played only an additional role. About 10 percent of rural households can be called kulturniki for getting their main income in agriculture - these were middle peasants answering the 1924 Bolsheviks' call and accepting the state offers to improve their land and technique. Thus, about a half of households waited for the opportunity to find better paid work in urban and industrial areas. They did not have a full-time job outside agriculture, and it was rational to work as part-time farmers leasing implements from other peasants (Merl, 199ob).

Lenin and other Bolshevik leaders did not want to give peasants the same rights with workers: they preferred to infantilize peasants (like women) as unable to make their own decisions. Workers were to guide peasants to the right way (similar to godparenthood). The Bolsheviks were afraid that otherwise peasants would succumb to wrong influence. The godparenthood-workers had to teach them to cultivate land and develop the right class consciousness. The denial of equal rights and refusal to recognize peasants' contribution to the revolution became evident in 1927: the October Manifesto for the 1oth anniversary of the Revolution gave privileges to all its participants except for middle peasants, which caused their harsh reaction and bitter disappointment (Merl, 2017a).

Ideologically Lenin's revision of his perception of peasants was determined by his interpretation of rural cooperation. He believed that cooperatives could never break the existing political order and argued that under the dictatorship of proletariat cooperatives could not endanger the Soviet rule. To avoid the risk of restoring capitalism peasants were to be organized in rural cooperatives. The new agrarian program was developed and implemented in 1924 under the slogan "litsom k derevne" (turn to the village). It focused on overcoming rural underemployment. Industrialization was to take place and not be labor intensive, so only a few peasants would have the chance to leave for industry. New jobs had to be created in agriculture and rural crafts, and hired labor and land leasing were allowed if registered.

The New Economic Policy quickly won the trust of peasants. The mid-1920s show a rise in agricultural productivity although there was no large-scale production. Not only industrial production but also small peasant farms achieved the pre-1913 per hectare yields. But the controversy among the Bolshevik leaders remained. They were more concerned with their conflicts than with developing a healthy basis for food production. Already in 1926, the idea of "litsom k derevne" was attacked. Stalin's forced grain procurement campaign of 1927- 
1928 made peasants lose the trust in the Soviet power again (Merl, 1993). In 1929, Stalin returned to the war communism agricultural policy using brutal force against peasants during collectivization. He not only denied the peasants of equal rights but in $193^{2}$ by the passport legislation turned them into forced workers with the only privilege to work in their home village.

Lenin tried to create a planned economy in agriculture on the basis of scientific research. Planning allowed to collect a huge amount of relevant empirical data. Scientists proposed measures for state intervention by economic incentives for peasants to improve agriculture. The chance for a quick increase in per hectare yields and sustainable improvement of the productivity of Soviet agriculture were quite high in the late 1920s. Russian experts played a leading role in the international agrarian research. Economic planning promised to transfer new agricultural knowledge into production, thus, facilitating a substantial rise in per hectare yields and husbandry production. Experts were sure to overcome the defects of peasant economy. To raise its productivity, they proposed land consolidation, progressive crop rotation, and selected seeds. Financial state support for this was available until 1928. Experts expected a significant growth in yields, and it started in the second half of the 1920s. They wanted the first fiveyear-plan to introduce an obligatory "agronomical minimum". The state had to provide subsidies to allow the poorest peasants to satisfy their needs. Stalin described this minimum as obligatory but at the same time stopped all financial support so that peasants made a "tribute" to industrialization (Merl, 2016; Merl, 1985a).

Experts' publications in the 1920s reveal economic perspectives of peasant economy. For example, they have data on the hidden unemployment. In the mid-1920s about 10 million employable people in the countryside were not needed for agricultural and craft production. This was a huge number - the total employment outside agriculture was only 10 million (Merl, 1993: 270-276). These data prove that it was not possible to solve the problem quickly. Stalin's collectivization in 1930 dramatically reduced the possible labor input in agriculture due to larger farms and mechanization. Moreover, with the loss of a half of livestock the possible labor input in this labor-intensive branch was strongly reduced. And peasants even lost their previous opportunities for side incomes from rural crafts for the state now took all raw materials for industry.

At the end of the 1920 s, the planners did not see prerequisites to move to the large-scale industrialized agriculture. The First FiveYear Plan in its "optimal version" adopted in April 1929 suggested that small farms would remain dominant for a longer time to deliver agricultural products for workers. Only after opening Soviet tractor enterprises, the general transition to large-scale enterprises in agriculture had to be completed in the mid-193os (Merl, $1985 \mathrm{~b})$. The planners made important proposals for future agricul-

\section{S. Merl}

Reassessment of the Soviet agrarian policy in the light of today's achievements 
ture. According to the Bolsheviks' aim to establish large-scale industrialized agriculture, they suggested in 1929 to start with integrating agricultural and industrial production and "agro-cities". Such combinations were designed for the area of about 20,000 hectares (Davies, 1974; Merl, 1985a). Huge state investments were required for such projects combining production and processing but were not provided.

\section{Forced collectivization}

With the "self-taxation" campaign in the early 1928 Stalin put previously autonomous peasant assemblies under the state control threatening everybody voting against state interests with arrests and repressions (Merl, 2012). He made peasant assemblies vote for self-taxation (and a year later for "voluntary" collective farms). Stalin destroyed the basis for legitimizing peasant rebellions. Their symbol - the church bell calling peasants to assemblies - was confiscated and melted for industrial needs. Stalin's mistrust to individual peasants soon was transferred to collective farms: he perceived kolkhoz$e s$ as enemies, put them under strong state control and denied them the right to organize production. The principle of "one-man leadership" guaranteed in 1931 for industry was not applied in agriculture. Kolkhoz heads and directors of state farms never became masters of their fields. The party always interfered in agricultural production to control every activity.

Kolkhozes were only allowed to possess implements for small-scale farming. From 1930, tractors and combine harvesters were supplied only to state farms or machine-tractor stations (MTS), i.e. were state property. MTS serving several kolkhozes were primary designed to secure state control over kolkhoz production. Together with political departments established in 1933 they were a means to discipline kolkhozniki rather than a way to modernize agriculture. From the mid1930 s, grain was expropriated directly from the fields leaving kolkhoz storage barns empty (Merl, 2016; Miller, 1970). For the most part, both MTS directors and kolkhoz heads lacked elementary knowledge of agricultural production for they had to execute party orders by intimidating their workforce.

From 1929, in a paternalizing manner the Soviet state made all decisions for agricultural producers not giving them an opportunity to decide for themselves on improving cultivation technology. Kolkhozes did not get any independence as enterprises or any degree of responsibility. They became totally dependent on the farming technology of MTS and lost control over schedule and quality of work on their fields. A rapid increase in yields would have needed autonomous agricultural enterprises that under local conditions could decide for themselves on the optimal use of improved agricul- 
tural technology and crop rotation. Moreover, in 1929, the decisive bond between wages and quality of work was lost. State agents often punished for a good-quality work by repeatedly imposing additional burdens on successful kolkhozes. Thus, the incentive system generally rewarded poor work (Merl, 2016). Only after Stalin's death, in the 1960s, the project of industrialized agriculture gained new life (Merl, 1988).

The party leadership was initially convinced that tractors and large-scale farming would guarantee progress in agricultural technology. They consciously accepted the concomitant destruction of peasant means of production for it was to be "compensated hundred times by the huge advantages of the new forces of production" (Merl, 1985 b: 184-211). In November 1929, Molotov explained that finances were to be got by the expropriation during collectivization (Merl, 1985a: 391397). However, he did not explain how investments would be made when peasant implements lost their market value. Land consolidation would become a prerequisite for improved work on fields by the use of tractors. Collectivization in the winter of 1929-1930 used mass violence against peasants for it no longer aimed at creating well-structured large-scale agrarian enterprises but rather "struggled for grain" and sought to subjugate peasants who supposedly were sabotaging the socialist development. The "dwarf kolkhozes" created in the early 1930s usually united a small number of peasant farms. With about 400 hectares they had only one tenth of the minimal land area planned for large-scale enterprises (Davies, 1979; Merl, 1985a: 331-400; Merl, 1990a: 61-128, 199-221).

Agrarian experts such as Moisei Volf, one of the designers of the first Five-Year Plan for agriculture, expressed concerns about hasty collectivization and fears about dramatic consequences of rural overpopulation (Merl, 1993: 487-493; Pravda 1928). The forced collectivization in the winter of $1929 / 1930$ was implemented without any organizational plan. The party leaders did not express their ideas on elementary questions such as how the kolkhoz should function. Only in March 1930, the Artel Statutes were published (Merl, 1990a: 199256 ). The abrupt replacement of small farms by kolkhozes and state farms cancelled all previous achievements in land distribution and consolidation, i.e. determined the loss of control over land. It was necessary to start from the beginning, and that could be done only after new enterprises had been stabilized. Under the forced collectivization the decisive prerequisite for productive crop rotation was lost for a long period. The growth of per hectare yields depended on available tractive power, so the loss of a half of working horses during collectivization worsened the situation: agricultural productivity decreased and poorly cultivated croplands were covered by weed. Until the late 1930s, the supply of tractors did not compensate for the loss in horse power. Only in the 1950s, the level of tractive power of 1928 was achieved again (Miller, 1974; Merl, 2016).

\section{S. Merl}

Reassessment of the Soviet agrarian policy in the light of today's achievements 
Nominally Stalin tried to continue new crop rotations and land consolidation. However, all campaigns failed for the crop rotation would have contradicted the ordered sowing for grain. Progressive crop rotations were to reduce grain fields but would have significantly increased per hectare grain yields (Merl, 2016). Providing grain for the state was an unconditional priority. The law "On the Protection of Socialist Property" drafted by Stalin in August 1932 extended the state demand for grain already at the stage of ripening. In the summer and autumn of 1932, some starving kolkhozniki were shot by this law because they had stolen ears from fields. Local authorities quickly understood that they were to deliver grain to the state under all circumstances. Therefore, they had no interest in introducing crop rotations, the only thing that mattered to them was a short-term success.

After the failure of his initial assault on peasants, Stalin had to make a similar concession in 1932 as Lenin did in 1921: under the famine of 1932-1933 he ended the arbitrary agricultural policy and returned to a tax in kind on grain, milk, meat and potatoes. The war communism approach to peasants failed for the second time leading to a terrible famine with more than 6 million victims. Stalin reacted to the famine caused by the brutal expropriation of agricultural products by fundamental changes in the agrarian policy, which proves that he considered the situation as very dangerous (Merl, 1990a: 128-140). In order not to jeopardize his rule he could not admit publicly that the forced industrialization and collectivization had caused a famine with millions victims. The established kolkhoz system was to put an end to the arbitrariness that agricultural producers experienced. This was a compromise between the interests of the state and peasantry. The return to the tax in kind as an obligatory delivery of agricultural products per hectare or cattle to the state ensured the state a very high proportion of agricultural products without paying all costs of production. By giving rights to private plots and "prepaying natural goods" during labor days (trudodni) the state finally gave kolkhozniki the chance to survive (Merl, 1990a: 129-140, 260-280, 360-371, 453-476).

The kolkhoz system existed from 1933 to the forced enlargement of kolkhozes in 1949-1953. It put an end to experiments with the industrialized agricultural production for two decades. By separating private plots from kolkhozes it preserved primitive forms of production. Under Stalin the kolkhoz economy remained limited to a small number of crops. Potatoes, fruits, vegetables, meat and milk products were mainly produced in the households. Cattle breeding in kolkhozes would have required large investments primarily in stables. The state prices did not cover production costs, and any increase in production or establishing new branches had to augment the losses of kolkhozes (and the unpaid "bonded labor" of kolkhozniki)(Merl, 199oa, 327-417).

The combination of state-controlled forced large-scale labor and small private plots within kolkhozes is a feature of Stalin's construction determined by peasant women's rebellion (babie bunty) in the 
early 1930s against confiscation of the last family cow under the forced collectivization. These local uprisings soon spread over the whole country and threatened Stalin's rule. He addressed peasant women and allowed peasants in kolkhozes to have a small private plot, one cow and some productive animals. This combination became a part of Stalin's model of socialist agriculture: while transferring collective farms to Eastern Europe, Stalin prescribed private plots for them too. For the agricultural modernization this was a counterproductive combination for it preserved primitive manual labor in the households. However, from 1933 it ensured peasants a chance to survive. Only in Hungary in the 1970s, this combination became a part of the successful model for collective farms supported private-plot production and helped to market its products at attractive prices.

In the late 1920s, yields in crop production and animal husbandry in the Soviet Union were still very low compared to European countries. In the 1930s, instead of growing they even decreased, which proves the failure of Stalin's large-scale agricultural enterprises. In grain and potatoes production, per hectare yields were on average $15 \%$ below those of small-scale farms; in sugar beet and cotton production, per hectare yields in the first half of the 1930 s fell even further. From 1935 they grew rapidly but did not reach the pre-1914 level. The growth of sugar beet and cotton yields were determined by a drastic increase in producer prices which covered production costs. For sugar beet production small groups were organized: they were responsible for all working operations. From 1935 cotton kolkhozes members received cash payments large enough to cover their food needs by market purchases. On the contrary, in potato and grain production state prices for their mandatory delivery covered only about 20\% of production costs (Merl, 2016: 40, 371-390).

After the good harvest of 1937 , for the first time after collectivization several kolkhoz members received sufficient grain for their needs for "labor days". Their reaction shocked the party leadership: many of them wanted to use this chance to escape from the forced institutional framework of kolkhoz and state "bonded labor", to return to individual farming and to determine one's own destiny - this required to own a horse, which was banned for kolkhozniki. The horse allowed the former kolkhoz member to become an independent small-scale entrepreneur for even rural state enterprises needed transport services. Families with many children also wanted to leave the kolkhoz due to the inability to feed their children. In 1938, the party leadership expressed concerns with these reports and accused local authorities of low payments (Merl, 1990a: 234-242, 247-256, 386-391). Stalin was upset that kolkhozniki were able to escape from the seemingly total state control by renouncing their kolkhoz membership. He called for slowing down the rush back to private farming and recommended to put pressure on kolkhozniki-"idlers" with few or no "labor days" (Tragediia sovetskoi derevni, 2006: 416-424). A campaign against "ex-

\section{S. Merl}

Reassessment of the Soviet agrarian policy in the light of today's achievements 
60 its" from the kolkhoz was launched and the horse tax was raised so much that no individual peasant could have a horse any more (Merl, история 1990a: 247-256, 386-391). In May 1939, the struggle against the "illegal extension of private plots" started (Tragediia sovetskoi derevni, 2006: 427).

The minimum number of labor-days was a blunder: the real problem was to provide kolkhoz members with paid work. Thus, forcing them to "work" the minimum number of labor-days meant forcing them to work without payment. This is why kolkhozniki worked so badly. Moreover, insufficient payment and seasonal labor made many of them seek paid work outside the kolkhoz or to focus on their private plot (Tragediia sovetskoi derevni, 2006: 90-97). As nominal "co-owners" of their kolkhoz they received only "labor days", i.e. worthless dashes on paper marking their share in "income distribution" at the end of the year, while in the neighboring kolkhoz they were paid in cash for the same work. Many non-cotton kolkhozes suffered heavy losses and did not have anything to distribute among their members at the end of the year. Rural dwellers income consisted of sales of their own products (not withdrawn as a tax in kind by the state) in the open market. A day of work on one's plot resulted in a significantly higher income than a "labor day" in the kolkhoz (Merl, 1990a: 371-417). The kolkhoz was basically a state enterprise, and kolkhozniki had to follow "recommendations" of the state if they wanted to avoid arrests. The state dictated not only every step of production but also distribution of the kolkhoz production. Collective farms served only the state interest not to pay monthly wages to kolkhozniki: as fictitious "co-owners" they were to distribute a never existing "profit" at the end of the agricultural year.

\section{Post-Stalin period}

Already in the last years of Stalin's rule many Soviet leaders recognized the need to change the approach to agricultural workforce, i.e. that it must be paid and get incentives for good work. However, only after Stalin's death in 1953 medium prices for agricultural producers tripled and the attack on private plots was stopped. Nevertheless, the paternalizing control of agriculture was not questioned by Khrushchev or Brezhnev. Although by the mid-196os qualification of kolkhoz heads and directors of state farms significantly improved and most of them got higher agricultural education, they were not allowed to become masters of their fields. The bureaucratic agricultural apparatus never stopped to provide them with detailed instructions, and they had to participate in all state agricultural campaigns of sewing, harvesting and sheltering cattle for the winter. Taking into account the miserable living conditions in the Soviet countryside in 1953, rejection of collective farms and returning to private farming (as later in Chi- 
na) would have contributed to a significant increase in yields. However, Hungary in the 1970s proved that large-scale agricultural cooperatives could be successful if they were allowed to control the whole production including selecting inputs, marketing, etc. Other limitations of the Soviet agro-industrial sector that are not considered in this article also did not change after Stalin's dead - investments in storage, processing, and trade were ignored by the planned economy until the very end of the Soviet period, which was one of the reasons why food produced in the West prevailed at Russian urban markets for a decade after 1992 .

Agricultural development under Khrushchev can be divided into two periods: successes and increasing yields until 1958, and stagnation and even decrease in per hectare and per animal yields in the following years. The first "successes" were not determined only by the virgin land program for the growth of agricultural production was also due to the liberalization of agrarian policy and to the rise of producer prices to the level of covering basic costs of production and allowing small money payments to kolkhozniki. As a result, they intensified production to provide urban population with products at kolkhoz markets. Until $195^{8}$ there was a hope that individual farming would be allowed again. As was situation with Stalin at the turn of the 1930s, Khrushchev's "dizziness by success" made him think that he had solved the agricultural problem, so his further decisions contributed to the new crisis. In 1958, he forced kolkhozes to buy the old machinery of MTS at the prices of new equipment so that kolkhozes would pay a tribute to the state space program as a part of the competition with capitalism. Therefore, the still extremely low income of kolkhozniki again stagnated or even declined. After the MTS were closed, most tractor and combine drivers left countryside not to become serfs as kolkhozniki for Khrushchev granted them in the MTS the status of workers with state social insurance (Merl, 2002).

Khrushchev's attempt to create "communist agriculture" contributed to the decline in animal husbandry. He forbade workers and employees to have cattle and started a campaign to force kolkhozniki to sell their cattle to kolkhozes at state prices significantly below market prices. Many preferred to slaughter their cattle and sell the meat at kolkhoz markets. Khrushchev also did not take into account that kolkhozes would need additional fodder for winter. The worst consequence of this communist project was that it finally destroyed the hope of returning to private farming, which caused the exodus of the most qualified rural workers that were so needed when Brezhnev started state investments in agriculture. People staying in the countryside did not have education, flexibility or interest to work. Many well educated specialists that were kolkhoz heads under Khrushchev's rule quit their jobs for they were fed up with crazy and harmful orders from above.

However, there was an alternative way to increase per hectare and per animal yields which was demonstrated by the experiment of the

\section{S. Merl}

Reassessment of the Soviet agrarian policy in the light of today's achievements 
62 tractor driver Ivan Khudenko. He addressed his reform proposal to Khrushchev who made him a director of the state farm in Kazakhstan.

история Khudenko reduced the workforce by $9 \circ$ percent and tractors by 75 percent, and with the remaining tractor drivers he tripled grain production and could even pay some money to those who had lost their jobs. Khudenko proved the super-fluousness of the huge state agricultural administration and the bureaucracy struck back: instead of being awarded with the order of Lenin he was arrested for "corruption" and died in prison (Merl, 1990c; Zhizn posle zhizni, 1989; Yanov, 1984).

This example is not an exception which is proven by a widespread phenomenon of shabashniki - highly motivated migrating teams of workers paid by cash by kolkhozes to do urgent work in a short period. Without motivation no kolkhoznik would fulfill such a task, so shabashniki supported the Soviet agriculture under the threat of arrest. Khrushchev called them "parasites" and they were often persecuted as "speculators" although kolkhozniki could be hired for cash by neighboring kolkhozes. The normal kolkhoznik's lack of motivation can be explained by "obezlichka", i.e. the lack of personal responsibility. Stalin had already mentioned this problem in industry in 1931, but the agricultural bureaucracy blocked any changes. Only those were awarded a premium who did a great work on huge areas although this was counterproductive for raising yields. Within the brigades it was hardly possible to decide who worked well of badly especially for the results became evident only after the harvest. This had a negative impact on the work discipline: why to work hard if the lazybones get the same payment? Only small teams from the mid-1930s showed better results.

In the mid-196os, for the first time in the Soviet history there were important state investments in agriculture. After the quick changes under Khrushchev's rule, agrarian policy became stable and determined some increase in yields but in the 1970s stagnation returned again. The most striking feature of the period was that the increase in capital inputs did not correspondent with a significant decrease in labor inputs. During harvest millions of students and industrial workers were sent to help in the countryside although the available rural workforce in the Soviet Union was five times larger than in the Western agriculture. The "lack of labor" was due only to the lack of work motivation of the majority of rural workers. Thus, capital inputs did not ensure raising yields or efficiency, for instance, huge investments in irrigation led to just one percent of annual increase in yields, while there was a significant increase in waste. Finally, the state had to cover losses of agricultural enterprises. Instead of forcing enterprises to increase efficiency by keeping producer prices stable, as the European Union successfully did, the Soviet state always preferred to increase subsidies to cover the raising costs.

Capital inputs under Brezhnev's rule were not smaller than today but it was the state rather than enterprises to decide on investments. 
The agricultural producer could not choose the type of machinery and had to take what the planned economy suggested. Hungary in the 1970 s showed that agricultural enterprises with free choice of investments could double corn yields in a few years by using Western machinery and competing service providers. Agricultural machinery produced by the Soviet industry did not meet Western standards in both quality and labor safety. Combine harvesters often caused huge harvest losses. Hardly any Soviet tractor or combine could work out the guaranteed period without breaking down, i.e. such machinery served interests of machinery producers rather than needs of agricultural enterprises. For the industry it was profitable to produce heavy machinery although it damaged the soil; the industry had no interest in producing spare parts, and under Brezhnev's rule already during the railway transportation new machinery mostly served as spare parts warehouse. Thus, when it reached the destination, it had only parts left that could not be used. Therefore, mechanization of agricultural work was never finished, and a lot of activities during harvest, in animal husbandry and milk production were still manual.

Instead of eliminating the "command system" in agriculture Brezhnev decided to introduce "socialist competition" to agricultural enterprises and workers. A huge state apparatus was busy with counting work results, awarding the winners and propaganda. Considering the stagnation of per hectare and per animal yields it is evident that such efforts had absolutely no effect for productivity. The attempt to overcome strong deficiencies of agricultural machinery by labor incentives was typical for the Soviet ideology claiming that success depended on the "right cadres" which was doomed to failure.

From the mid-1950s there was an intensive knowledge exchange with the West: many soviet specialists were send abroad to study, and according to the archives of the Soviet Ministry of Agriculture every progress in the West was known in the Soviet Union. Models of efficient Western machinery, animal breeds, hybrid seeds, equipment for producing concentrated fodder and milk were imported. Some models were developed by Soviet research institutions for Soviet mass production but the agricultural machinery producers were not able or willing use this knowledge. Moreover, the Soviet countryside lacked transportation capacities until the very end of the Soviet period and also lacked qualified labor needed for more developed machinery. As a result, in the early 1970s a large amount of grain was imported for food: first imports were due to the bad harvest in 1963 to avoid a heavy decline in livestock.

With the calls to the "fermer" and return to private farming at first radical reformers had a great success: peasants were allowed to work on their own without state interference. In the early 1990s, a minority of rural workforce, about 240.000 families, decided to become fermers while the majority of new fermers were not previously rural workers but rather industrial workers, townspeople or the leading
63

\section{S. Merl}

Reassessment of the Soviet agrarian policy in the light of today's achievements 
64 and qualified personnel of collective farms with good local networks to organize their farms. Collective and state farms without any deистория sire had to provide fermers with land. The fermers' movement shows to what extent some people were fed up with state paternalism and wanted to become their own masters. Many of them had more idealism than knowledge of agricultural production although many managed to get a tractor, farming implements and irrigation equipment. I met some fermers in 1992 and 1993 and believe that about 10 percent of them could become successful peasants with modern farms of several hundred hectares. It was not their fault that almost all of them failed by the mid-199os; many stayed in the countryside and worked on their private plots.

The main reason for their failure was agricultural depression that started in 1992 after liberalization of prices that revealed an excessive demand for meat products. Liberalization of prices halved the demand for meat - to the level expected from the general industrial development in Russia. Many urban consumers preferred to buy well packed and better processed meat products imported from the West. Fermers never got access to urban markets for the control of transportation and marketing of food products was quickly taken by local mafia groups that made producers pay for "protection". There was no need to raise production but to produce agricultural products more efficiently to sell them in the market without losses. The quality of processing, storage, transportation and marketing neglected during the Soviet period now became the Achilles heel of the Russian agricultural producers.

At the same time serious mistakes of the radical reformers became evident: they correctly estimated the efficiency of labor inputs in the Soviet agriculture as very low but were too much focused on the idea of private property and did not take into account the necessary size of peasant farm under today's agricultural technology. Fermers usually got 40 hectares but had no chance to lease or buy additional land or to use their land property as a deposit to get credits to improve their farming. 40 hectares under the Russian extensive production were insufficient. For instance, under the transition to the market economy in the GDR the medium size of new peasant farms was about $15^{\circ}$ hectares; thus, in Russia from 500 to 1000 hectares would have been necessary. It took Russian legislation more than 10 years to eliminate restrictions on private land property but only agricultural holdings benefited from it.

\section{Putin's agriculture: Rapid growth of yields, risky focus on agroholdings}

Unlike the Soviet past, today, after privatization, agroholdings pursue their personal gains and are masters of their fields free from admin- 
istrative interference in production decisions. The state uses economic levers and subsidies to guide the development of agriculture in the desired direction. These subsidies make investments in agriculture attractive even for non-agricultural capital owners. Although the production itself always has losses, state subsidies and food exports ensure significant profits (Wegren, Nikulin, Trotsuk, 2018). The rapid growth of per hectare and per animal yields is determined by the use of Western machinery and livestock breeding equipment, seeds and cattle breeds. The "green revolution" taking place in Russia mainly in agroholdings and some peasant farms finally introduces new agricultural technology and achievements of industrial agriculture (Merl, 2015).

Putin's agricultural policy tried to support private farmers; however, the lack of experience in selecting promising peasants and especially the widespread corruption determined that only a minor part of state subsidies was provided to active peasants. Moreover, in recent years they lost state protection for the state allows land-grabbing by agroholdings. "Household farms" are successors of the Soviet private plot production and a separated part collective farms that does not take part in the "green revolution": only very few of them want to become peasants or lease machinery. The majority of them are the elderly without qualification producing just some additional food for their own consumption. The state is very at risk relying primarily on speculative large agro-holding production dependent on state subsidies for there is a high risk of losses and failures for capital owners especially considering the scale of agro-holding production - many of them have more than 200.000 hectares under cultivation.

Thus, the growth of per hectare and per animal yields in Russia from the early 2000 s prove that the low Soviet yields cannot be explained by bad soil or climate. A different approach allowing agricultural producers - large-scale enterprises and peasant farms - to master their fields and investments, production and marketing would have made already Stalin's agriculture efficient enough to feed the working class, to support industrialization and to export food after the World War II. In the 1920s, the Soviet Union successfully used economic levers to increase yields and improve peasant agricultural technology but in 1929 the situation changed radically - Stalin focused on state compulsion and deprived agricultural producers the right of making decisions on agricultural production and of getting adequate payment.

These are the features determining the results of the Soviet "socialist" agriculture:

- The Bolsheviks did not trust peasants and later heads of collective and state farms. They considered them as counter-revolutionaries, incompetent farmers and unreliable allies incapable of efficient agricultural production. Thus, only in short periods of liberalization in 1953,1965 and 1985 there was some increase in yields.

\section{S. Merl}

Reassessment of the Soviet agrarian policy in the light of today's achievements 
- The quality of Soviet agricultural machinery and equipment lagged far behind the Western standards at least from the 1950s. Moreover, there were no mechanized equipment for private plots. Soviet agricultural equipment never allowed to fully mechanize the production especially in preparing hay and fodder and dairy production. Stalin's “industrialized agriculture" was designed for the aims of control rather than modernization of production.

- $\quad$ From the 1870s to the very end of the Soviet period the rural sector suffered from the hidden unemployment. While in the developed capitalist countries 1-2 percent of the workforce produce enough food for the population, in the Soviet agriculture even in the 1980s more than 10 percent of the workforce was employed. Soviet agricultural labor productivity was only 1020 percent of the capitalist countries level, which is determined by the loss of motivation in the Soviet agricultural regime that alienated people from the results of their work. This loss of motivation became the main factor of the steady negative trend in yields under the Soviet rule. Stalin's state demanded that peasants worked as serfs engaged in bonded unpaid labor. According to the radical reformers in the late 1980s, collectivization turned peasants into agricultural workers without any interest in the results of their work. Thus, the Soviet agriculture definitely did not lack labor, and the "felt" lack of labor was the result of the lack of motivation to work.

- In the 1920s, hardly any other country had so many agricultural experts as the Soviet Union, and the level of agricultural scientific research was high until the end of the Soviet period. However, this and also Western knowledge was not applied in the everyday production of collective and state farms. The role of Soviet experts was ambivalent: they were scapegoats for failures of the Soviet agriculture and had to provide "bacchanalian" plans so that the party leadership would hide its dilettantism in managing agricultural production, which led to huge differences between optimistic images of the plans and sad realities of rural life.

\section{References}

Ascher A. (1988) The Revolution of 1905, vol. 1: Russia in Disarray, Stanford.

Channon J. (1989) The Bolsheviks and the peasantry: The land question during the first eight months of Soviet rule. Slavonic and East European Review, vol. 66, pp. 593-624.

Danilov V., Shanin T. (Eds.) (2002) Krestjanskoe dvizenie v Povolzie, 1919-1922 gg.: Dokumenty i materialy [Peasant Movement in the Volga Region in 1919-1922: Documents and Data], Moscow (In Russ.).

Davies R.W. (1974) The Soviet rural economy in 1929-1930. The size of the kolkhoz. C. Abramsky (Ed.) Essays in Honour of E.H. Carr, London: Macmillan, pp. 255-28o. 
Davies R.W. (1979) The Industrialization of Soviet Russia, vol. 1: The Socialist Offensive. The Collectivization of Soviet Agriculture 1929-1930, London: Macmillan.

Figes O. (1989) Peasant Russia, Civil War: The Volga Countryside in Revolution (1917-1921), Oxford.

Krebs C. (1983) Die weltanschaulichen und wirtschaftstheoretischen Grundlagen der Agrartheorie im Marxismus-Leninismus, Berlin.

Merl S. (1985a) Die Anfänge der Kollektivierung in der Sowjetunion: Der Übergang zur staatlichen Reglementierung der Produktions- und Marktbeziehung im Dorf (1928-1930), Wiesbaden: Otto Harrassowitz, pp. 166-213.

Merl S. (1985b) Handlungsspielräume und Sachzwänge in der sowjetischen Wirtschafts- und Sozialpolitik der Zwischenkriegszeit. W. Fischer (Ed.) Sachzwänge und Handlungsspielräume in der Wirtschafts- und Sozialpolitik der Zwischenkriegszeit, St. Katharinen: Scripta Mercaturae Verlag, pp. 175-229.

Merl S. (1988) Hat sich der landwirtschaftliche Großbetrieb bewährt? Zum Vergleich von Agrarentwicklung und Agrarproblemen in der Sowjetunion und der DDR. H. Horn, W. Knobelsdorf, M. Reiman (Eds.) Der unvollkommene Block: Die Sowjetunion und Ost-Mitteleuropa zwischen Loyalität und Widerspruch, Berlin: Berlin-Verlag, pp. 139170.

Merl S. (1990a) Bauern unter Stalin: Die Formierung des sowjetischen Kolchossystems 19301941, Berlin: Duncker \& Humblot.

Merl S. (199ob) Socio-economic differentiation of the peasantry. R.W. Davies (Ed.) From Tsarism to the New Economic Policy. Continuity and Change in the Economy of the USSR, London, pp. 47-65, 254-261, 350-353.

Merl S. (1990c) Steht die Reprivatisierung der sowjetischen Landwirtschaft bevor? Deutsche Studien, vol. 28, pp. 289-305

Merl S. (Ed.) (1993) Sowjetmacht und Bauern. Dokumente zur Agrarpolitik und zur Entwicklung der Landwirtschaft während des “Kriegskommunismus" und der Neuen Ökonomischen Politik, Berlin: Duncker \& Humblot, pp. 15-78.

Merl S. (2002) Entstalinisierung, Reformen und Wettlauf der Systeme 1953-1964. Handbuch der Geschichte Rußlands. Bd. 5: 1945-1991. Vom Ende des Zweiten Weltkriegs bis zum Zusammenbruch der Sowjetunion, Stuttgart, pp. 175-318.

Merl S. (2010) Kann der Korruptionsbegriff auf Russland und die Sowjetunion angewandt werden? N. Grüne, S. Slanicka (Hg.) Korruption. Historische Annäherungen an eine Grundfigur politischer Kommunikation, Göttingen, pp. 247-279.

Merl S. (2012) Politische Kommunikation in der Diktatur. Deutschland und die Sowjetunion im Vergleich, Göttingen.

Merl S. (2015) Kak udalos Stalinu vosprepjastvovat "zelenoj revolyutsii" v Rossii? K voprosu o tormozhenii agrarno-technicheskogo progressa (1927-1941) [How did Stalin manage to prevent the Green Revolution in Russia? On the obstacles to the agrarian-technical progress (1927-1941)]. Krestyanovedenie. Teoriya. Istoriya. Sovremennost. Uchenye Zapiski, no 10, pp. 88-147 (In Russ.).

Merl S. (2016) Why did the attempt under Stalin to increase agricultural productivity prove to be such a fundamental failure? On blocking the implementation of progress in agrarian technology (1929-1941). Cahiers du Monde Russe: Terres, Sols et Peuples: Expertise Agricole et Pouvoir (XIX-XX siècles), vol. 57, no 1, pp. 191-220.

Merl S. (2017a) Traditionalistische Widersetzlichkeit oder politische Programmatik? Russlands Bauern im Kräftefeld von Agrarreform und revolutionärer Mobilisierung (1856-1941). Zeitschrift für Agrargeschichte und Agrarsoziologie, no 65, pp. 73-94.

Merl S. (2017b) Sovetskaya ekonomika: sovremennye otsenki [Soviet economy: Contemporary estimates]. Ekonomicheskaya istoriya. Ezhegodnik 2016/17, Moscow, pp. 303349 (In Russ.).

Miller R.F. (1970) One Hundred Thousand Tractors: The MTS and the Development of Controls in Soviet Agriculture. Cambridge: Harvard University Press.

Pravda, 6 June and 11 July 1928.
67

S. Merl

Reassessment of the Soviet agrarian policy in the light of today's achievements 
Rossiiskii statisticheskii ezhegodnik 2006 [Russian Statistical Yearbook 2006] (2007), Moscow (In Russ.).

Rossiiskii statisticheskii ezhegodnik 2013 [Russian Statistical Yearbook 2013] (2014), Moscow (In Russ.).

Rossiiskii statisticheskii ezhegodnik 2017 [Russian Statistical Yearbook 2017] (2017), Moscow (In Russ.).

Schedewie F. (2006a) Selbstverwaltung und sozialer Wandel in der russischen Provinz. Bauern und Zemstvo in Voronez, 1864-1914, Heidelberg.

Schedewie F. (2006b) Sozialer Protest und Revolution im Landwirtschaftlichen Zentrum Rußland: die Bauernaufstände im Kreis Ostrogozsk, 1905-1907. H.-D. Löwe (Ed.) Volksaufstände in Rußland. Von der Zeit der Wirren bis zur "Grünen Revolution" gegen die Sowjetherrschaft, Wiesbaden, pp. 453-496.

Selskoe khoziaistvo SSSR. Statisticheskii sbornik [USSR Agriculture. Statistical Yearbook] (1988), Moscow (In Russ.).

Tragediia sovetskoi derevni: Kollektivizatsiia i raskulachivanie. Dokumenty i materialy [Tragedy of the Soviet Village: Collectivization and Dekulakization: Documents and Data] (2006): v 5 tomakh. 1927-1939, vol. 5, part 2, Moscow (In Russ.).

Wegren S.K., Nikulin A., Trotsuk I. (2018) Food Policy and Food Security. Putting Food on the Russian Table, Lexington: Lanham et al.

Yanov A. (1984) The Drama of the Soviet 196os. A Lost Reform, New York.

Zhizn posle zhizni. Esche raz o sudbe ekonomista i khleboroba Ivana Khudenko [Life after life. Once again on the fate of the economist and grain-grower Ivan Khudenko] (1989). Izvestiya. 27.12.1989 (In Russ.).

\section{Переоценка результатов советской сельскохозяйственной политики в свете сегодняшних успехов}

Штефан Мерль, доктор исторических наук, профессор Билефельдского университета; Университетская ул., 25, 33615, Билефельд, Германия. E-mail: smerl@uni-bielefeld.de.

Очевидные успехи политики В.В. Путина требуют переоценки советской сельскохозяйственной модели. Автор задается вопросом, насколько большевистский подход учитывал чаяния российского крестьянства, и рассматривает ограничения "социалистического индустриального сельского хозяйства". Чтобы оценить достижения советского сельского хозяйства, автор опирается на показатели урожайности и надоев с 1913 года, поскольку на протяжении всего советского периода они оставались стабильными в том смысле, что были поразительно низкими для сельского хозяйства, основанного на крупномасштабном и отчасти механизированном производстве. Разрыв в урожайности с соседними капиталистическими странами увеличивался с 1930 по 1991 годы. Значительный и устойчивый рост урожайности с 2000 года не позволяет объяснять неудачи советского сельского хозяйства плохими почвами, особенностями климата или природными ограничениями - виной всему была сельскохозяйственная политика. Вопреки якобы "революционному обновлению" социалистическое сельское хозяйство даже в годы всемирной "зеленой революции" не продемонстрировало ни одного значительного скачка производительности. Автор видит основную причину этого в "инфантилизации" сельскохозяйственных производителей (крестьян, глав колхозов и совхозов) вследствие недоверия и скрупулезного контроля "сверху". В советский период сельхозпроизводители не распоряжались своими полями. Ситуация ухудшилась, когда плановая экономика в 196о-е годы обеспечила сельское хозяйство недостаточным количеством неэффективной техники, не соответствовавшей 
западным стандартам. Хотя необходимое оборудование и знания об организации 69 производства можно было получить на Западе, в Советском Союзе не завершилась механизация растениеводства и животноводства. Статья начинается с описания запросов, поведения и ожиданий крестьянства в ходе революций 1905 и 1917 годов, затем, уделяя особое внимание кратким периодам роста урожайности - 1924-1930, 1953-1958, 1965-1970 и 19861991 - автор обращается к основам советской сельскохозяйственной политики, разработанным В.И. Лениным и И.В. Сталиным, предлагает краткий обзор подходов к сельскохозяйственному развитию, предложенных Н.С. Хрущевым, Л.И. Брежневым и М.С. Горбачевым, и завершает статью обозначением причин успешности политики В.В. Путина.

Ключевые слова: социалистическое сельское хозяйство, сельскохозяйственная политика, индустриальное сельское хозяйство, инфантилизация крестьян, классовая дифференциация, В.И. Ленин, И.В. Сталин, Н.С. Хрущев, Л.И. Брежнев, М.С. Горбачев, В.В. Путин. 